\title{
The Commonwealth Games as an Example of Bringing States Closer Through Sport
}

\section{Authors'contribution:}

A) conception and design of the study

B) acquisition of data

C) analysis and interpretation of data

D) manuscript preparation

E) obtaining funding

\section{Michał Marcin Kobierecki}

University of Lodz, Poland

The aim of the article is to investigate the issue of positive sports diplomacy directed at bringing countries closer and deepening cooperation between them. Generally, sports diplomacy is a broader term and may include various ways of utilizing sport, both negative and positive, even for the sake of nation-branding. Positive sports diplomacy most commonly refers to bringing hostile states closer together, but it may also be used to deepen political alliances or foster friendship and cooperation between states that are not mutually hostile. The research focuses on the latter form of positive sports diplomacy. The investigation is a case study concerning the Commonwealth Games, a sports event that is held once every four years and gathers countries and territories that used to belong to the former British Empire. The research therefore aims to determine whether this event, the second largest multisport event in the world, is significant from political and diplomatic perspectives. A second research question concerns whether the Commonwealth Games should be seen as an attempt by Great Britain to maintain influence in its former colonies. The research attempts to test the hypothesis that the Commonwealth Games are an important contributor to sustaining ties between states of the former British Empire.

Sports diplomacy, politics and sport, Commonwealth Games, Great Britain

\section{Introduction}

The political significance of sport has long been investigated by researchers representing various fields of science. However, the issue of sports diplomacy is relatively new in scientific research. The term itself is understood differently by various authors. It may be perceived as both the utilization of sport for the sake of rapprochement between states, and the exercise of sports contacts as a tool for maintaining international conflicts. These two types of sports diplomacy may sometimes be called positive and negative, respectively, but both of them use sport to foster the foreign policy objectives of states. Moreover, sports diplomacy can be perceived as part of public diplomacy, and therefore may be used as a soft power resource to create the desired image of a country.

The aim of this article is to investigate one of the forms of positive sports diplomacy. This form is usually associated with the case of the famous Ping Pong diplomacy, in which communist China and the United States used a table tennis exchange in order to break the isolation and achieve rapprochement between their states, which had until this point been hostile to each other. Friendly sports matches allowed 
for the arrangement of a politically safe channel for contact and acted an outlet for testing the readiness of the respective societies for a breakthrough in bilateral relations. Positive international sports diplomacy also has other forms that are not necessarily bilateral or existing solely between hostile countries. Sport may also be used by countries to deepen an already existing friendship, cooperation, or political alliance, as when the Soviet Union and its satellite countries or non-aligned states attempted to enhance their relationship through the Games of New Emerging Forces (GANEFO).

The subject of this research is the above-mentioned utilization of sport for the sake of deepening cooperation between states based on the example of the Commonwealth Games. Therefore, this is a case study. A number of similar events based on regional, cultural, or historical backgrounds also exist, such as the Pan American Games, African Games, Central American and Caribbean Games, Asian Games, Mediterranean Games, Maccabiah Games, Pacific Games, Bolivarian Games, and Lusophony Games. All of these events have, to some extent, brought nations closer together through sport, for example within a region or continent. From the diplomatic, political, and organizational perspectives, there are, however, two events that appear to be the most important: the Commonwealth Games and Jeux de la Francophonie, which are comparable to the Commonwealth Games but for the French colonial empire. They both have an extraregional dimension. This study will focus on the Commonwealth Games.

The aim of the research is to observe the mechanism of bringing states closer together and building a political alliance using a periodical sports event. The Commonwealth Games is an event in which countries belonging to the Commonwealth of Nations compete. This is an organization of states that formerly belonged to the British Empire. As Ali Mazrui (2014) described it, the Commonwealth Games are an event in which states that used to be ruled by Great Britain test each other with regard to their sports skills.

The article attempts to answer the research question of whether the Commonwealth Games are diplomatically and politically significant, or are just another sports event. The other research question is whether the Commonwealth Games should be seen as Great Britain attempting to maintain influence over its former colonies. The research encompasses an analysis of motivations for organizing this event through the analysis of formal documents and statements of the Commonwealth Games Federation, British monarchy, media releases, etc. This should allow for the testing of the hypothesis that the Commonwealth Games are an important contributor to sustaining ties between the states of the former British Empire.

\section{Characteristics of the Commonwealth Games}

The Commonwealth Games are recognized as the second most important multi-sport event in the world, after the Olympic Games (Houlihan, 2014). Some authors even describe the Games as a sports megaevent (Parent, 2008). There are also opinions claiming that the Commonwealth of Nations gains most of its publicity from this sports event (Murphy, 2013). In this context, the Commonwealth of Games could also be investigated from the perspective of sports diplomacy directed at branding, both concerning the organization and the hosting of respective events by particular countries. However, this is not the subject of this particular study. Still, the weak popularity of this event in non-Commonwealth countries may downplay its greater significance worldwide.

The Commonwealth Games are organized once every four years, in the mid-term between the Olympic Summer Games. A total of 71 teams from 50 countries belonging to the Commonwealth of Nations are eligible for participation in this event. The sports program is not permanent and changes from one event to another. Traditionally, athletes have competed in ten sports: swimming, track and field, and eight other individual sports determined by the host of the event (Kaufman \& Slettedahl, Macpherson, 2005; Commonwealth Games Federation, 2014a). The number of competitions has changed since 1998. For example, during the Commonwealth Games in Glasgow in 2014, athletes competed in 17 sports (Caplan \& Smith, 2005; Jolly, 2013). Currently, the minimal number of sports at the event is ten, and competitions can be held for a maximum of four team sports (Tomlinson, 2010; Commonwealth Games Federation, 2014b). Hosts of the Commonwealth Games often try to adjust the sports program to their own specificities; for 
example, when India was hosting the Games in Delhi in 2010, kabaddi, one of the county's national sports, was introduced to the program (Lipoński, 2012).

When describing the Commonwealth Games, it is important to explain the difference between the number of states belonging to the Commonwealth of Nations and the number of teams that participate in the event. This stems from the fact that a number of states are represented by more than one team. For example, Great Britain is represented by England, Wales, Scotland, Northern Ireland, the Isle of Man, and the Channel Islands (Coghlan \& Webb, 1990).

The history of the Commonwealth Games dates back to 1930, when the first of such events was initiated by Melville Mark "Bobby" Robinson. According to him, the event was supposed to be a sort of a response to the nationalism and fierce rivalry present during the Olympic Games, an event that was gaining popularity and political significance at the time. Unlike the Olympics, the British approachto the spirit of sports and fair play was to be the most important element of the projected event (Oliver, 2014). Initially, the name of the event was the British Empire Games; the name later changed as the Commonwealth of Nations evolved. Between 1950 and 1962, the event was called the British Empire and Commonwealth Games; between 1966 and 1974, it was called the British Commonwealth Games. The current name has been used since 1978 (Caplan \& Smith, 2005; Levinson \& Christensen, 1996). These changes were obviously connected to the decolonization and dissolution of the British Empire and the increasingly even roles of the participating nations.

Although the Games have been held since 1930, the need to establish such a sports event was suggested even earlier. The Festival of the Empire held in London in 1911, during which competitions in boxing and wrestling were organized, can be regarded as a forerunner of the future Commonwealth Games (Panton, 2015). Even earlier, in 1891, Englishman John Astley Cooper proposed an idea concerning the need to organize such event. According to him, it would be a tool for enhancing goodwill and understanding within the British Empire - in other words, it would work to strengthen the bonds between the countries and territories of the empire (Groom, 2014; Williams, 2012; Mojumdar, 2009). Cooper proposed organizing an event under one of the following names: the Pan-Britannic and Anglo-Saxon Festival; the United English Festival; the Olympic Festival of the British Empire; the Athletic Pan Anglia, Pan-Britannic, and AllAnglian Gathering; and the Pan-Britannic Contest (Lipoński, 2012; McIntyre, 1991; Guttmann, 2002). Those motivations for organizing the event refer to the investigated issue of using sport to bring states closer together, although the structure of international relations at that time differed greatly from contemporary times.

As has been noted, the objectives behind the establishment of the Commonwealth Games included maintaining the bonds between the states and territories of the British Empire. It is worth noting that in the early days of the event, the Games mostly concerned relations between Anglo-Saxon members of the community - Great Britain, Canada, Australia, and New Zealand - and the former colonial countries that would now be described as belonging to the Global South (Black \& van der Westhuizen, 2004). One could suggest that once the British Empire disintegrated, the Commonwealth Games became a tool for maintaining British influence in its former colonies. However, there is no evidence to support this notion. It appears more reasonable to claim that the event was rather oriented towards maintaining international ties.

\section{Diplomatic and political significance of the Commonwealth Games}

The aim of maintaining bonds between the countries and territories of the British Empire was visible from the beginning of the Commonwealth Games. Surprisingly, when political ties between these respective countries began to deteriorate in the twentieth century, cultural ties were simultaneously strengthened. This led to the organization of the first British Empire Games in Hamilton in Canada (Toohey, 2010). It is believed that in the first years of the independence of Canada, this event was used as one of the main pillars for maintaining sports bonds with Great Britain (Houlihan, 1997). In spite of this, it appears that the diplomatic significance of the Commonwealth Games did not increase until later. It is believed that when the Commonwealth of Nations began to lose its position in global politics, the significance of the 
Commonwealth Games began to grow (Houlihan, 2000). This leads us to the conclusion that, as in other forms of positive sports diplomacy that aim to bring countries closer together, an activity directed at increasing sports bonds could also indirectly affect political ties. This mechanism is also used in public diplomacy when non-political exchanges and communications are meant to produce positive emotions towards a particular country in a targeted society.

The Commonwealth Games are often referred to as the Friendly Games, which stems from the friendly atmosphere that is believed to exist during the events (Coghlan \& Webb, 1990). The Commonwealth Games are also much less commercialized than contemporary sport in general, and - at least theoretically - there are no other objectives of organizing this event apart from those of maintaining bonds between the countries that used to be connected through the British Empire (Oliver, 2014). Owing to this friendly atmosphere, and in a way as a form of resignation from the exaggerated competitiveness and gigantism typical of the contemporary Olympic Games, the Commonwealth Games are sometimes described by historians as a "strong but elastic link of former ties to Britain" (Tomlinson, 2010). On the other hand, it is often suggested that the Commonwealth Games emphasize the Commonwealth as a family of nations (Jolly, 2013). The organizers of this event share this belief. According to the Constitution of the Commonwealth Games Federation (2014b), the basic principles of the event include the development of sport for the benefit of the people, nations, and territories of the Commonwealth of Nations. The Games are also supposed to strengthen the Commonwealth. These statements clearly imply that the Commonwealth Games are in fact organized at least to some extent with the purpose of fostering rapprochement between these countries who share a common past. The all-encompassing emphasis on friendliness during the Games appears to be directed at eliminating nationalistic attitudes that are sometimes evoked during sports competitions. The other objective is to broaden the identity of the people of the Commonwealth of Nations and encourage a feeling of closeness and kinship. Here it can be observed that the initiative is most of all directed at ordinary people. This is another reference to the public diplomacy that can be seen in the diplomatic mechanisms of the Commonwealth Games.

The Commonwealth Games' objective of bringing the participating countries closer together can be derived not only from the formal documents of their organizers and the desired friendly atmosphere, but also from the extensive symbolism included in the event. The Queen's Baton Relay appears to be particularly worth mentioning. It resembles the Olympic torch relay and its traditions date back to 1958. The route of the relay always starts in the Buckingham Palace, while the last participant of the relay hands the baton to the Queen or her representative during the opening ceremony of the Commonwealth Games. The Queen's Baton Relay became a symbol of the unity and diversity of the member states of the Commonwealth of Nations (British Monarchy). The baton is supposed to travel through each of the countries competing in the Games, and there is a hidden message from the Queen inside. For example, in the message regarding the Commonwealth Games in Glasgow in 2014, the Queen stated that the "baton relay represents a calling together of people from every part of the Commonwealth and serves as a reminder of our shared ideals and ambitions as a diverse, resourceful and cohesive family" ("Bring it on", 2014). Here as well we can observe a strong emphasis on the closeness of the nations of the Commonwealth, which is to be strengthened even more through the Commonwealth Games.

It should be noted that even though the Commonwealth Games are supposed to evoke good feelings between the nations according to all objectives and principles, the event has occasionally become a target of a sports boycott, which can be included in the category of negative sports diplomacy. These boycotts have mostly been the result of different attitudes concerning how to solve the problem of white minority regimes in Africa. In 1966, Zambia withdrew from participating in the Commonwealth Games in Kingston in response to the lack of an agreement regarding economic sanctions for Rhodesia (Good, 1973). The problem was intensified fourteen years later concerning the Commonwealth Games in Edmonton when African countries protested against New Zealand maintaining sports contacts with South Africa. The Canadian government engaged diplomatic channels in order to solve the problem. It attempted to reach a compromise between New Zealand and the African countries. What is more, the government of Canada stopped issuing visas to athletes and officials from South Africa, which was welcomed by the African member states of the 
Commonwealth. In the end, all of the African member states except Nigeria, Uganda, and Botswana sent teams to the event (Macintosh, Greenhorn \& Black, 1999; Abegunrin, 2009). This situation obviously had a negative context, but nonetheless speaks for the argument that the Commonwealth Games plays a unifying role. A similar problem could not be resolved before the Olympic Games in Montreal two years earlier, as the event was boycotted by many African countries. In the case of the Commonwealth Games, a compromise may have been easier to come by, as a sort of rapprochement between New Zealand and the African Commonwealth member states was eventually reached. Of course, one might point out that the African countries were simply less interested in boycotting the sports event after their Olympic boycott did not succeed in its political goals. Still, the specificity of the Commonwealth Games probably also played a role.

In a discussion of boycotts of the Commonwealth Games, we should not forget about the event that occurred in Edinburgh in 1984. As before, the problem was connected to apartheid in South Africa. The South African government responded to international pressure by adopting a new constitution in 1984. The document introduced a catalogue of laws describing the benefits that Indians and colored people were entitled to. Nevertheless, people with black skin living in the country did not benefit from the new legislature. This led to social unrest, and the South African government responded with repression. In July 1985, the South African president, Pieter Willem Botha, placed the country under emergency rule. As a result, the international community imposed economic sanctions on South Africa (Levy, 1999).

This situation resulted in a dispute within the Commonwealth of Nations. Most of the member states wanted to impose severe sanctions, while the prime minister of Great Britain, Margaret Thatcher, preferred a more gentle approach. It was most difficult to reach a common view on the promotion of tourism in South Africa (International Labour Organization, 1990). It appeared that consensus was possible as the Commonwealth Accord on Southern Africa, also known as the Nassau Accord, was accepted. The agreement established a soft package of sanctions and included the establishment of the Commonwealth Eminent Persons Group. Its members were supposed to investigate the South African issue and endorse political dialogue in order to end apartheid in the Republic of South Africa (Cay, 1985). The Accord also stated that the emergency state in South Africa should end, political prisoners including Nelson Mandela should be freed, and aid to both sides should be discontinued. A dialogue was to be initiated in order to create a nonracial, representative government. It was assumed that if the situation did not improve within six months, more severe steps against South Africa would be taken (Cobley, 2001).

The objectives of the Nassau Accord were not reached. On the contrary, the South African army struck targets in neighboring Botswana, Zimbabwe, and Zambia, and a state of emergency was imposed on the whole country in June 1986. Commonwealth member states apart from Great Britain wanted to make the sanctions more severe. In this situation, many member states of the Commonwealth of Nations called to boycott the 1986 Commonwealth Games that were to be held in Edinburgh in Great Britain (Macintosh \& Hawes, 1994). Nigeria was the first to respond to this call and declared a boycott on July 9, 1986 (Inamete, 2001). Other countries soon followed suit. In the end, the Games were boycotted by 32 countries (Lloyd 2007; Tiwari \& Singh, 2008; Commonwealth Games Federation, 2014c), although other authors claim that 33 states resigned from participation in the event (Booth, 1998). The boycott is believed to have been one of the most effective of all boycotts in the history of sport. It involved approximately half of all the countries that were supposed to participate in the Games and had a negative effect on the event. The country that was the target of the protest was also the host of the event, so the boycott struck the proper target, not an innocent victim, which has sometimes occurred during other sports boycotts. These developments can be assessed as an intrusion on the whole spirit of the cooperation-oriented Commonwealth Games. Fortunately though, this situation did not have a long-term negative effect on either the Commonwealth Games or the Commonwealth of Nations. 


\section{Conclusions}

The Commonwealth Games can be assessed as one of the supreme examples of using sport to maintain bonds between historically related countries and their societies. The Games are a form of so-called track-two diplomacy, which aims to evoke the desired attitudes of ordinary people, as this is the target of communication that appears to be particularly effective for sports events. Despite the passage of time and the evolution of international sport, the Commonwealth Games appear to be succeeding in retaining their original form and reaching the original objectives of fostering cooperation and friendship between countries that used to be ruled by Great Britain. This can be seen in the official statements of the Commonwealth Games Federation, comments of athletes and journalists about the events, and the extensive symbolism that underlines the importance of fostering friendship and cooperation through the Games. Thus, the hypothesis that the Commonwealth Games are an important contributor to sustaining ties between states of the former British Empire appears to be highly probable.

The success of the Commonwealth Games can also be seen in the fact that postcolonial sentiments are hardly recognizable during this event. The history of sport contains many situations in which people from former colonies have expressed anger or even hostility towards former colonial empires. The Games of New Emerging Forces or the Supreme Council of Sport in Africa are just a few examples of initiatives that have aroused such sentiments. Still, the author of this article failed to find any relevant examples of such feelings during the Commonwealth Games.

Of course, in the long history of the Commonwealth Games, the event has at times become a victim of the political power struggle concerning attitudes towards the minority regime in the Republic of South Africa. This led to a massive boycott of the event in Edinburgh in 1986. Still, such situations appear to have been easier to solve than those that arose in mainstream international sport; in the end, such events have not influenced the original, peaceful message of the Commonwealth Games.

The research allowed for the observation that the Commonwealth Games should not be perceived as a tool of Great Britain in maintaining control and influence over its former colonies. It is true that originally the Games were intended to help shape relations between Anglo-Saxon countries and colonies, but over time the formula of the event appears to have become democratic. Participation in the event is voluntary and references to the British monarchy seem to be purely symbolic, rather than reflecting British desires to dominate.

\section{Acknowledgements}

The research has been financed by the National Science Centre of Poland, project number 2015/19/D/HS5/00513.

\section{REFERENCES}

Abegunrin, O. (2009). Africa in Global Politics in the Twenty-First Century: A Pan-African Perspective. New York: Palgrave Macmillan.

Black, D.R. \& van der Westhuizen, J. (2004). The allure of global games for "semi-peripheral" polities and spaces: A research agenda. Third World Quarterly, 25(7), 1195-1214. DOI: 10.1080/014365904200281221.

Booth, D. (1998). The Race Game: Sport and Politics in South Africa. London - Portland: Routledge.

Bring it on: Queen delivers baton's message as she officially opens Glasgow 2014 Games. (2014, July 23). The Herald. Retrieved December 23, 2016, from:

http://www.heraldscotland.com/sport/13171452.Bring_it_on_Queen_delivers_baton_s_message_as_she_officially_op ens_Glasgow_2014_Games/.

British Monarchy. (2014). The Commonwealth Games: The Official Website of the British Monarchy. Retrieved December 23, 2016, from:

http://www.royal.gov.uk/MonarchAndCommonwealth/QueenandCommonwealth/TheCommonwealthGames.aspx.

Caplan, G. \& Smith, P. (2005). Sport. Oxford: Harcourt Education Limited. 
Cay, L. (1985, October). The Commonwealth Accord on Southern Africa - Nassau Accord. Retrieved October 29, 2015, from: http://www.anc.org.za/show.php?id=4896\&t=The\%20Commonwealth\%20of\%20Nations.

Cobley, A. (2001). Institutionalized violence and the role of human sympathy: The case of the Eminent Persons Group to South Africa. In E. Barriteau \& A. Cobley (Eds.), Stronger, Surer, Bolder. Ruth Nita Barrow: Social Change and International Development (pp. 3-16). Kingston: University Press of the West Indies.

Coghlan, J.F. \& Webb, I.M. (1990). Sport and British Politics Since 1960. New York: Routledge.

Commonwealth Games Federation. (2014a). The Story of the Commonwealth Games. Retrieved December 23, 2016, from: http://www.thecgf.com/games/story.asp.

Commonwealth Games Federation. (2014b). Constitution. Regulations. Code of Conduct. July 2014. Retrieved December 13, 2016, from: http://www.thecgf.com/about/constitution.pdf.

Commonwealth Games Federation. (2014c). 1986 Commonwealth Games. Retrieved October 18, 2015, from: http://www.thecgf.com/games/intro.asp.

Good, R.C. (1973). U.D.I: The International Politics of the Rhodesian Rebellion. New Jersey: Princeton University Press.

Groom, G. (2014). The Complete Book of the Commonwealth Games. Web publication: Lulu.com.

Guttmann, A. (2002). The Olympics: A History of the Modern Games. Urbana and Chicago: University of Illinois Press.

Houlihan, B. (1997). Sport, Policy and Politics: A Comparative Analysis. London: Routledge.

Houlihan, B. (2000). Politics and sport. In J. Coakley \& E. Dunning (Eds.), The Handbook of Sports Studies (pp. 213227). London: SAGE.

Houlihan, B. (2014). The Government and Politics of Sport. London: Routledge.

Inamete, U.B. (2001). Foreign Policy Decision-Making in Nigeria. Cranury - London - Mississauga: Susquehanna University Press.

International Labour Organization. (1990). Special report of the Director-General on the application of the declaration concerning action against apartheid in South Africa and Namibia. Geneva: International Labour Conference, 77th Session, 1990.

Jolly, R. (2013). Commonwealth Games: Friendly rivalry. In Research Papers Series, 2013-14. Parliament of Australia. Retrieved October 8, 2015, from:

http://parlinfo.aph.gov.au/parlInfo/download/library/prspub/2825633/upload_binary/2825633.pdf;fileType=application $\% 2$ Fpdf.

Kaufman, W. \& Slettedahl Macpherson, H. (Eds.) (2005). Britain and the Americas: Culture, Politics, and History: A Multidisciplinary Encyclopedia (vol. I). Santa Barbara: ABC-Clio.

Levinson, D. \& Christensen, K. (Eds.) (1996). Encyclopedia of World Sport. Oxford: Oxford University Press.

Levy, P.I. (1999). Sanctions on South Africa: What Did They Do?New Heaven: Yale University.

Lipoński, W. (2012). Historia sportu na tle rozwoju kultury fizycznej. Warszawa: PWN.

Lloyd, L. (2007). Diplomacy with a Difference: The Commonwealth Office of High Commissioner, 1880-2006. Leiden: MNP.

Macintosh, D., Greenhorn, D. \& Black, D. (1992). Canadian Diplomacy and the 1978 Edmonton Commonwealth Games. Journal of Sport History, 19(1), 26-55.

Macintosh, D. \& Hawes, M. (1994). Sport and Canadian Diplomacy. Montreal - Buffalo - London: McGill-Queen's University Press.

Mazrui, A.A. (2014). The Politics of Gender and the Culture of Sexuality: Western, Islamic and African Perspectives. Lanham: UPA.

McIntyre, W.D. (1991). The Significance of the Commonwealth, 1965-90. Basingstoke: Palgrave-Macmillan.

Mojumdar, R.M. (2009). History of Physical Education and Sport. New Delhi: Sports.

Murphy, P. (2013). Monarchy and the End of Empire: The House of Windsor, the British Government and the Postwar Commonwealth. Oxford: Oxford University Press. 
Oliver, B. (2014). The Commonwealth Games: Extraordinary Stories Behind the Medals. London: Bloomsbury.

Panton, K.J. (2015). Historical Dictionary of the British Empire. Lanham: Rowman \& Littlefield Publishers.

Parent, M.M. (2008). Mega sporting events and sports development. In V. Girginov (Ed.), Management of Sports Development (pp. 147-164). Oxford: Routledge.

Tiwari, S.R., Rathor, C.L. \& Singh, Y.K. (2008). History of Physical Education. New Delhi: A.P.H. Publishing Corporation.

Tomlinson, A. (2010). Dictionary of Sports Studies. Oxford: Oxford University Press.

Toohey, K. (2010). Commonwealth Games. In R. Barlett, C. Gratton \& C. Rolf (Eds.), Encyclopedia of International Sports Studies (pp. 283-284). London: Routledge.

Williams, D. (2012). Commonwealth Games, England. In J. Nauright \& C. Parrish (Eds.), Sports Around the World: History, Culture, and Practice (vol. I; p. 55-56). Santa Barbara: ABC-Clio.

AUTHOR'SADDRESS: $\quad$ Michał Marcin Kobierecki

University of Lodz

Faculty of International and Political Studies

Składowa 43

90-217 Lodz

Poland

E-mail: mkobierecki@uni.lodz.pl

Received: 23 December 2016; Accepted: 30 January 2017 